\title{
A Recepção da Escola Positiva e da Escola Clássica no Pensamento Criminológico Brasileiro pela Ótica de Moniz Sodré e Filinto Bastos
}

\author{
The Reception of Positive School and Classical School in Brazilian \\ Criminological Thinking by the Optic of Moniz Sodré and Filinto Bastos
}

\author{
Rebeca Fernandes Dias ${ }^{1,2}$ \\ 'Pontifícia Universidade Católica do Paraná, Curitiba, PR, Brasil \\ ${ }^{2}$ Faculdade UniDomBosco, Curitiba, PR, Brasil
}

Resumo: O presente artigo analisa como um célebre embate da Ciência Criminal (final do século XIX e primeira metade do XX), a disputa entre Escola Clássica e Escola Positiva, vai se reproduzir no cenário brasileiro a partir de dois grandes juristas, referências no período e professores de Direito Criminal de Faculdades de Direito da época: Moniz Sodré e Filinto Bastos. O primeiro é divulgador e adepto confesso da Escola Positiva, enquanto o segundo defende os postulados da Escola Clássica. De lados opostos nessa "disputa" da Ciência Criminal, ambos, todavia, declaravam-se liberais. Contradição? A metodologia escolhida é a de caráter teórico-exploratória da literatura disponível e levantada.

Palavras-chave: Escola Positiva. Escola Clássica. Liberalismo.
Abstract: The present article analyzes how a famous clash of Criminal Science (late nineteenth and first half of XX), the dispute between Classical School and Positive School, will be reproduced in the brasilian scenario, from two great jurists, references in the period and Criminal Law professors at Law Schools in that period: Moniz Sodré and Filinto Bastos. The first, promoter and confessed adept of the Positive School, while the second will defend and assume the Classical School postulates. From opposite sides in this Criminal Science "dispute", both, however, declared themselves liberal. Contradiction? The methodology chosen is the theoretical-exploratory of the available and raised literature.

Keywords: Postive School. Classic School. Liberalism.

Recebido em: 15/06/2019

Revisado em: 30/11/2019

Aprovado em: 21/04/2020 


\section{Introdução}

Em 18 de novembro de 1882, Enrico Ferri anuncia formalmente a Nova Escola Positiva de Direito Penal. Sua emergência decorreria do exaurimento da Escola, iniciada por Beccaria e encerrada por Carrara e outros integrantes, por ele intitulada, Escola Clássica. A Nova Escola buscava compreender o crime como um fenômeno concreto e natural, devendo-se investigar, portanto, suas causas naturais, por meio do método experimental, em face da Escola Clássica que o concebia como um ente jurídico e abstrato, a partir do método dedutivo e silogístico.

A Nova Escola Positiva apresentava mudanças significativas no universo do direito e da Ciência Criminal: o fundamento do direito de punir passa a se apoiar na defesa social; nega-se o livre-arbítrio e a liberdade moral (parte-se do determinismo), negando-se em consequência a imputabilidade que nesta se baseava; o delinquente, e não o crime (autor e não o ato), torna-se o protagonista da Ciência Criminal; a pena é determinada de acordo com a temibilidade do delinquente e não pela gravidade do ato; há, portanto, uma classificação de delinquentes; a prevenção adquire centralidade no âmbito político, econômico, administrativo, educativo, familiar; propõem-se reformas no âmbito do processo penal e do ordenamento judiciário (SBRICCOLI, 2009). Uma vez que a defesa social passa a ser o fundamento do direito de punir, a sanção será vista como meio de defesa contra o delinquente - torna-se uma técnica de neutralização, por meio da eliminação, segregação e terapias de adaptação, correção dos sujeitos.

No cenário da Ciência Criminal, então, sobretudo a partir do anúncio oficial de Ferri, parece se estabelecer um intenso combate entre as Escolas, o que acarreta a valorização das teses mais extremas e agressivas, e mais passíveis de produzir senso comum (SBRICCOLI, 1998).

Cabe então verificar se houve uma dualidade/disputa doutrinária na Ciência Criminal brasileira; verificar especificamente como, no processo de afirmação do Estado Republicano e de modernização da sociedade (fim do século XIX e início do século XX), manifestam-se na Ciência Criminal brasileira as disputas dos discursos e que relação tiveram com o discurso liberal, que também se afirma como legitimador do governo 
republicano, pois, como bem pontua Rafael Queiroz, “Os republicanos vendiam a nova ordem política como fator potencializador de direitos individuais e políticos, cujo desenvolvimento o Império não favoreceria" (QUEIROZ, 2007, p. 49).

$\mathrm{Na}$ esfera da Ciência Criminal brasileira, essa disputa entre Escolas foi explicitamente recepcionada pelos juristas, na passagem do século XIX para o século XX. No âmbito de uma pesquisa mais extensa ficou bastante clara a recepção da dualidade, criada por Ferri, Escola Clássica X Escola Positiva, na cultura jurídica brasileira. ${ }^{1}$ Neste artigo, pretende-se focar a análise a partir dos juristas Moniz Sodré e Filinto Bastos, professores de direito criminal no período estudado e que contavam com projeção nacional. Esses juristas acabam sendo bastante emblemáticos para se analisar a recepção deste combate de Escolas no âmbito da Ciência Criminal, pois cada um adere de maneira confessa e convicta a cada uma

${ }^{1}$ Este artigo é fruto de uma pesquisa de doutorado, a qual analisa a recepção do pensamento criminológico na cultura jurídica criminal do Brasil, no período da Primeira República, mais especificamente no âmbito do ensino do direito criminal. Para o estudo foram selecionadas algumas das Faculdades de Direito importantes na época (São Paulo, Recife, Rio de Janeiro, Bahia e Curitiba) e levantados, no que foi possível, os programas das disciplinas de direito criminal, para selecionar os juristas e na sequência seus textos, dos quais se buscou interpretar como se deu este processo de recepção e em que medida os novos parâmetros do direito criminal, influenciados pela Criminologia Positivista, foram assimilados na cultura jurídica da época. A chave de leitura para a interpretação dos textos foi a dualidade do Liberalismo, que se expressa como um ideário de afirmação de direitos e garantias individuais, ao longo do século XIX, mas que foi também marcado por cortes de exclusão e, portanto, combinou-se, na prática, com mecanismos de poder e controle, em nome da segurança e defesa da sociedade. A Criminologia Positivista e o Direito Criminal, reconstruído a partir de seus parâmetros, emergem em um contexto, na Europa, de fissuras do Liberalismo, em razão de inúmeras contingências sociais e políticas e no Brasil às vésperas da Proclamação da República, a qual ocorria após o fim da escravidão e, portanto, em um momento de expectativas de inclusão e ampliação das liberdades. A adesão gradativa aos princípios da chamada "Nova Escola de Direito Penal", no âmbito da doutrina, é cada vez mais significativa ao longo das primeiras décadas do século XX e esta adesão, no discurso dos juristas, não se confrontava com os princípios liberais, mas era com estes combinada. Esta combinação foi um dos focos de análise da pesquisa, pois, por meio dela, sobretudo, pode-se identificar como o pensamento criminológico articulou-se no discurso destes juristas (DIAS, 2017). 
das Escolas, como se verá. ${ }^{2}$ Curiosamente, a despeito desta divergência no campo Criminal, ambos eram liberais. O que poderia parecer contraditório, sobretudo para Moniz Sodré, adepto da Escola Positiva.

A Escola Positiva pressupõe o campo de tensão por trás do princípio da legalidade, pois foca no lado oposto ao escolhido pelo Liberalismo Penal da primeira metade do século XIX (a que Ferri intitula de Escola Clássica): privilegia os sujeitos em face do sistema objetivo de delitos e penas; leva em conta as diferenças antropológicas, a despeito da suposta igualdade jurídica, destaca a Política Criminal em face do Direito Penal; tem como fundamento a defesa social e não a liberdade do indivíduo (COSTA, 2007).

Todavia, o que poderia parecer uma contradição, na verdade, para o jurista brasileiro estava longe de o ser, como se verá em sua argumentação. Uma argumentação que não apenas usa truques de retórica para harmonizar dois supostos opostos, Liberalismo e Positivismo Penal, mas que na verdade colocava à mostra uma dualidade do próprio discurso liberal, o qual se sustentava na dialética ordem/liberdade, que, por sua vez, pressupunha uma dualidade de sujeitos: os proprietários e as classes perigosas, uma dualidade que no discurso Criminológico do Positivismo Criminal passa a ser retratada entre homens normais e honestos $\mathrm{X}$ homens anormais e criminosos.

\footnotetext{
${ }^{2}$ Um dos critérios de escolha dos juristas para integrar a pesquisa mais ampla mencionada na nota 1 foi: ser professor de Direito Criminal na época estudada (1889-1930), para que então se pudesse analisar de que forma esses juristas teriam absorvido as Teorias Criminológicas, que então circulavam, e as transmitiam em suas aulas. A escolha dos juristas, nesse artigo, apresentados deu-se na medida em que ambos foram professores de Direito Criminal no período estudado e apresentaram uma produção teórica que permitiu a análise à qual a pesquisa se propôs (a recepção das Teorias Criminológicas). Moniz Sodré ainda contou com projeção nacional, uma vez que sua obra, analisada nesse estudo, As três escolas penais, foi reeditada inúmeras vezes, o que pode indicar o quanto era consultada pelos juristas da época. Filinto Bastos mostrou-se interessante não só por preencher os critérios já mencionados, mas também por ter uma postura tão incisiva e ao mesmo tempo destoante para a época: a defesa inegociável da Escola Clássica, mostrando-se uma voz um tanto isolada em um coro nacional que bradava os méritos e avanços da Escola Positiva.
} 


\section{Moniz Sodré e a Propagação dos Postulados da Escola Antro- pológica Positiva}

Moniz Sodré nasceu em 13 de junho de 1881 na cidade de Salvador. Formou-se em Direito pela Faculdade de Direito da Bahia em 1903. Lecionou nesta e no Rio de Janeiro Direito Criminal, inclusive no curso de doutorado da Faculdade Nacional de Direito da Universidade do Brasil. Já em 1907 publicou sua obra mais conhecida, As três escolas penais, que o consagrou como jurista. Foi deputado estadual e federal por várias vezes e senador federal da Bahia, de 1920-1926. Foi diretor do Diário da Bahia, dirigiu no Rio o Correio da Manhã. Foi Procurador-Geral do Estado do Rio de Janeiro e Secretário do Interior e Justiça. Proclamava-se defensor da liberdade e dos ideais democráticos. Em discurso de Paraninfo dos Bacharelandos em 1931 da Faculdade de Direito da Bahia, assim declarou:

Orgulho-me em ser um espírito revolucionário, para as conquistas da liberdade, a cujas magnificências rendo o culto de minha ardente devoção, porque ela, a liberdade, constitui elemento imprescindível, a condição primeira para a felicidade dos homens e a dignidade dos povos [...] O despotismo é, portanto, a fonte de todas as desgraças, ainda que seja o despotismo branco, que concede generosamente a liberdade como dádivas de favor. $\mathrm{O}$ despotismo dissimulado, hipócrita, lavrado, é a morfina da tirania [...] Prefiro a tirania franca e violenta, em plena ostentação de seu poder desvairado, à ditadura falsa e mentirosa que, por entre melífluas promessas de liberalismo insincero, espolia de todas as garantias os nossos direitos, pondo a propriedade, a vida, a liberdade, a honra, de todos os cidadãos sob discrição exclusiva do capricho pessoal do poder [...] os homens são apenas instrumentos dóceis e quiça inconscientes [...] na marcha evolutiva de sua acidentada trajetória pelo báratro da vida, até atingir o píncaro de seus nobres ideais de perfeição. (SODRÉ, 1977, p. 8-10)

Ressaltando seu viés democrático, afirmava Evandro Moniz Corrêa de Menezes, nas apreciações biográficas de Sodré: 
E a palavra eloquente ainda há pouco verberava, com o seu habitual fulgor, contra a tirania e os tiranos. Nessa época, as hordas vandálicas do nazi-fascismo se exibiam no auge do poder, causando abalos profundos em espírito como o seu, que se mostrava, entretanto, malgrado a sua incontida revolta, certo da vitória final da Democracia nesse grande combate. (SODRÉ, 1977, p. 13)

Declaradamente liberal, democrático e, como se verá, exímio defensor da Escola Positiva do Direito Penal e um dos grandes divulgadores de suas ideias.

As duas obras centrais de Moniz Sodré para o presente estudo são As três escolas penais, cuja primeira edição data de 1907, que teve grande ressonância na cultura jurídica penal das primeiras décadas do século XX (contando com algumas reedições), bem como seu Curso de Direito Criminal, parte 1. Em ambas as obras Moniz Sodré faz uma explanação bastante didática e completa das diferentes correntes penais, resgatando historicamente seus antecedentes e analisando-as a partir de seus principais pontos de divergência. Em As três escolas penais apresenta o fundamento da responsabilidade criminal do criminoso, o conceito de crime, o homem criminoso, o conceito e os efeitos da pena, conforme o ponto de vista das três Escolas (Clássica, Antropológica, Crítica), como indica no título. Pode-se perceber que corresponde a uma obra muito mais densa e analítica que a de Viveiros de Castro, A Nova Escola Penal (1894), com objetivo para além de informar, divulgar as ideias positivas. No Curso de Direito Criminal, após algumas explanações gerais como o enquadramento do Direito Penal no âmbito das Ciências Jurídicas e a sua importância, discorre sobre o fundamento de punir, a lei penal e o crime também e sempre a partir das três Escolas.

O autor explica no prefácio da quarta edição de As três escola penais, que esta corresponde ao estudo do Direito Penal como Ciência Social, enquanto o seu curso seria o estudo do Direito Penal como Ciência Jurídica, sendo o direito como Ciência Social "[...] a base, a fonte inspiradora do direito como Ciência Jurídica” (SODRÉ, 1977, p. 18). Por isso, o autor considera As três escolas penais como uma espécie de introdução ao seu curso, com noções propedêuticas de Direito Criminal. Para não 
incorrer em explanações demasiadamente detalhadas e até mesmo repetitivas, a análise das obras se fez, sobretudo, a partir das ideias centrais que o autor discute de acordo com as três Escolas, selecionando trechos em que o autor deixa clara a sua filiação em relação à Escola Positiva Antropológica. Justamente por isso acabou se privilegiando a análise de As três escolas penais, por ser um texto em que o autor assume uma missão mais propagandista e divulgadora e, portanto, suas críticas são mais certeiras e seu posicionamento mais explícito (embora não deixe de ficar clara sua adesão à Escola Antropológica em seu Curso de Direito Criminal). Além disso, como bem explica o autor, em As três escolas penais, sua análise é do Direito Penal como Ciência Social e este foco de estudo para a presente pesquisa é mais fértil do que sua explanação na obra Curso de Direito Criminal.

Em As três escolas penais apresenta Beccaria e sua obra Dos delitos e das penas como pedra angular dos sistemas clássicos; Lombroso acompanhado de Ferri e Garofalo os mentores da Escola Positiva e Colajanni, Alimena, Lacassagne, Tarde, Prins e Liszt como formadores da Escola Eclética, a qual se liga à Escola Positiva pelo método, mas diverge de algumas conclusões da Antropologia Criminal (estre os juristas brasileiros adeptos desta Escola situa Clovis Bevilacqua e José Higino) (SODRÉ, 1977). Na verdade, quanto à Escola Crítica Sodré busca identificar muito mais pontos de semelhança com a Escola Antropológica do que divergências $^{3}$.Uma das críticas centrais de Sodré à Escola Clássica refere-se jus-

3 "Para ambas (antropológica e crítica), o direito repressivo tem por fundamento a necessidade de defesa social, para ambas muito rara e dificilmente se obtém, com a aplicação da pena, a regeneração dos criminosos, máxime se não se trata de jovens delinquentes; para ambas, os meios preventivos, na luta contra o crime, são muito mais eficazes do que as medidas repressivas". O desacordo versa apenas sobre pontos secundários e questões acessórias, segundo Sodré. "Consiste: 1) em que a escola antropológica não distingue a penalidade dos outros instrumentos de defesa social; 2) em assinalar às penas um maior ou menor poder de prevenção contra o crime, pela intimidação que exerce sobre o espírito comum dos indivíduos, por isso a escola italiana vê nos meios repressivos uma insignificante resistência às avalanches de criminalidade, enquanto a terceira escola, acorde neste ponto com a doutrina clássica, julga que a punição dos culpados é por si só um freio, não raro, suficiente para impedir o aumento dos crimes." (SODRÉ, 1977, p. 249-250). 
tamente à falsa premissa da igualdade fundamental de todos os homens, honestos ou criminosos, fazendo deste princípio pedra angular do monumento de suas teorias jurídico-abstratas e de suas doutrinas "[...] sem que o tivesse jamais sujeitado ao cadinho da experiência, a fim de verificar se ele se harmonizava com a verdade dos fatos, inteligentemente observados" (SODRÉ, 1977, p. 34). Para ele, os clássicos arquitetavam teorias no ar, brilhantes, embora falsas e mentirosas.

Defende Lombroso contra as críticas que consideravam simplistas as análises do mestre italiano. Para Sodré, tratava-se de uma visão desleal, daltônica e deformadora, que ignorava o exame minucioso e complexo que Lombroso teria feito do homem criminoso, não se limitando a análises anatômicas e físiognômicas, mas abrangendo caracteres somáticos, patológicos e psíquicos. Afirma como incontestável a verdade a que Lombrosos teria chegado, de que um dos fatores precípuos da criminalidade é a constituição orgânica e psíquica do malfeitor, cuja individualidade física e moral deve constituir, mais do que o crime, o objeto da Ciência Criminológica. Compara a concepção antropológica do delinquente, como conquista da Criminologia, à doutrina de Darwin do transformismo evolucional na luta pela existência.

Considera a Antropologia Criminal a Ciência mais fecunda das Ciências Biológicas, por suas aplicações práticas em poder assegurar as condições de existência da sociedade na luta contra a criminalidade. Luta cuja eficiência depende do princípio norteador de que o criminoso é uma variedade antropológica à parte do tipo moral do homem desenvolvido e civilizado. Para Sodré, as teorias explicativas dessa profunda desigualdade biológica, somática ou psíquica, podem ser discutidas e negadas, "Mas o reconhecimento dessa desigualdade se impõe hoje à consciência de todos os cientistas, como uma verdade suprema, absolutamente inderrogável" (SODRÉ, 1977, p. 52).

Considera ainda criticamente que a Escola Clássica não teria conseguido definir exatamente o delito. Definir crime como aquilo que a lei o define como tal é cair em um círculo vicioso ou no mais puro arbítrio: 
O raciocínio é este: - o crime é a violação da lei penal; a lei penal é a vontade dos legisladores, logo o crime é filho desta vontade, e o seu conceito deles está dependente. Poderíamos, por conseguinte, definir: - crime é a vontade do legislador - fórmula que encerra em si o que o despotismo tem de mais odioso e a tirania de mais aviltante. (SODRÉ, 1977, p. 102)

Ao invés de classificações antropológicas de criminosos, os clássicos insistem nas classificações dos crimes "[...] mais ou menos arbitrárias, e de valor científico quase nulo" segundo Sodré. O crime como entidade abstrata seria o objeto "quase que exclusivo das suas especulações metafísicas” (SODRÉ, 1977, p. 128). A reação que alguns juristas clássicos teriam contra essa visão da Escola Positiva, como Filinto Bastos (professor de Direito Criminal da Faculdade Livre da Bahia, que em breve será analisado), de que a Escola Clássica aborda sim o criminoso, apenas não a partir da premissa de que é um ser anômalo, embora verdadeira, de acordo com Sodré, não elimina a crítica de seu método apriorístico e seu desconhecimento das Ciências Físico-naturais, portanto, embora de certa forma considerem o criminoso, não levam em consideração muitos aspectos que passam a ser centrais a partir de uma análise mais complexa (fisio-psico-social), como a positiva.

Considera que a Escola Clássica atribui mais valor à objetividade do ato do que à subjetividade do agente, ou seja, a intenção criminosa, e lamenta que

[...] essa doutrina absurda e imoral, repugnante aos sentimentos naturais de justiça e senso moral do comum dos homens honestos, está consignada nos dispositivos legais do nosso código criminal, modelado, como é, pelo espírito da Escola Clássica. (SODRÉ, 1977, p. 134)

A proporcionalidade da pena e do delito (quanto maior o dano, o alarma social e maior a culpabilidade moral do agente, mais grave a pena), um dos fundamentos da Escola Clássica, é vista com desprezo por Sodré. Para ele, "É incontestável a dificuldade enormíssima, e não raro invencível, com que lutam os adeptos da Escola Penal metafísica, para, na 
prática, aplicar com justiça o princípio, para eles fundamental, da proporcionalidade das penas aos delitos" (SODRÉ, 1977, p. 138).

Sodré defende a tese do tipo criminoso e rebate as objeções a ela a partir de Ferri. Neste momento é curioso notar que os criminólogos, tão orgulhosos de seu método experimental e positivo em analisar o delinquente, partem de uma premissa metafísica sobre o crime, porque deslocado de tempo e lugar. Veja-se: uma das objeções à teoria do tipo era justamente a que, partindo-se da premissa da indeterminação do crime na história, ou seja, se o crime varia historicamente, como se pode definir um tipo de homem criminoso? A resposta de Ferri, apresentada por Sodré, é a de que esta premissa da indeterminação não é completamente verdadeira, pois aplica-se apenas a um universo de criminalidade, a criminalidade evolutiva, e não à criminalidade constituída pelos delitos fundamentais, de caráter atávico e anti-humano - essa comporta certos crimes que, embora variem os critérios de punição, sempre foram crimes em qualquer sociedade e em todos os tempos -; assim, parece que de alguma forma os criminólogos acreditam em um núcleo de justiça absoluta e recaem, ironicamente, nas armadilhas da Metafísica a partir do terreno do Positivismo Evolucionista.

Assim defende Sodré:

Cremos [...] que se fosse possível sujeitarem-se a um exame antropológico completo os grandes criminosos de outras eras, neles se encontrariam os principais estigmas que caracterizam os delinquentes contemporâneos [...] Em resumo, de tudo que temos dito deve concluir-se que a existência do tipo antropológico do delinquente está demonstrada pela realidade dos fatos colhidos pela experiência, e que ele resulta de um conjunto de caracteres anatômicos, fisiológicos, patológicos, fisionômicos e psicológicos; mas que todos estes caracteres não têm a mesma importância, um valor igual como indício da criminalidade. Os estigmas anatômicos, fisiológicos e patológicos são apenas sinais certos de degenerência, provam somente que os indivíduos que os apresentam são seres anormais; mas tais estigmas não são sinais característicos e sintomáticos da delinquência por si só não distinguem os delinquentes dos outros degenerados. A fisionomia especial dos criminosos e, mais do que tudo, as suas anomalias psíquicas e que são os caracteres especí- 
ficos verdadeiramente patognômicos da criminalidade. (SODRÉ, 1977, p. 170)

Defende a responsabilidade social e a temibilidade como critério da punição, ou seja, escolha e medida da pena, mas é contrário ao sequestramento com base apenas no perigo, visto como um atentado aos direitos invioláveis da personalidade e às garantias individuais do cidadão. $\mathrm{O}$ sequestramento deve ocorrer em decorrência de um ato criminoso, único sinal revelador da perigosidade do indivíduo. Nesse sentido, critica a incoerência de que exatamente os criminalistas que defendem o criminoso como ser normal (menciona expressamente Prins e Liszt) e que pleiteiam a ele um direito protetor, são os

Que sustentam devam ser processados e sentenciados indivíduos pelo fato de parecerem perigosos antes de praticarem qualquer ato delituoso, o que consiste um atentado à personalidade humana, assim arbitrariamente ferida nos seus direitos invioláveis, cujas garantias estão no princípio de nulla pena sine legis. (SODRÉ, 1977, p. 186-187)

Sodré está atento às críticas à Escola Antropológica que partem do despotismo do argumento da defesa social, ou seja, da ideia de que por detrás do manto da defesa social qualquer ato de arbítrio se justifica. Isso quer dizer que o autor não ignorava as objeções que se faziam à Escola a partir do ângulo mais liberal de proteção aos direitos individuais e do princípio da legalidade. Tendo isso em vista, defende a Escola Antropológica, primeiramente utilizando um argumento ferriano, de que a história demonstra uma sucessão de abusos e um sangrento martirológio de vítimas, embora o direito de punir se fundasse na mais absoluta justiça divina e, ainda, a partir do argumento de que essa Escola busca, sim, o equilíbrio entre os direitos individuais e as garantias sociais - tanto é assim, sustenta o jurista brasileiro, que para combater o abuso de poder seus adeptos recomendam a ação penal popular (não restando ao exclusivismo do Ministério Público), reparação dos erros judiciários em benefícios dos injustamente condenados e processados e a exclusão de fatos tidos como 
crimes que passariam a ser meros delitos civis. Assim, analisa este suposto equilíbrio:

É certo que a escola antropológica não faz como a clássica que, a começar de Beccaria, o seu real fundador, muito se esforçara para rodear progressivamente a personalidade do criminoso das maiores garantias, mesmo em prejuízo da justiça, e contra os interesses da própria sociedade. Mas se no século XVIII era justificável esta corrente de idéias generosas em prol dos delinquentes como uma nobre reação contra as medidas bárbaras e crueldades processuais da idade média, hoje, que não se pode mais aceitar a teoria errônea do Estado inimigo do individuo, torna-se indispensável uma contra-reação em seu tempo útil e necessária, como um forte paradeiro e baluarte irredutível aos caprichos cegos da tirania. Mas convém lembrar ainda que se a escola metafísica surgiu com um programa em que vinha gravado o lema da defesa dos indivíduos acusados contra as exorbitâncias do poder, todavia o seu individualismo ficou incompleto e unilateral, sempre imperfeito, porquanto a pessoa e os interesses da vítima dos crimes foram sempre descurados, e jamais mereceram dos criminalistas clássicos uma atenção especial, preocupados como estavam com a idéia de proteção dos delinquentes. (SODRÉ, 1977, p. 340)

Dessa forma, pode-se perceber que Sodré está preocupado em justificar as críticas à Escola Antropológica que concebiam nela um perigo para os direitos individuais. Clamando-se um democrático e liberal, poderia não parecer muito coerente sua filiação a uma Escola à qual se vinculava a possibilidade de abuso de poder. O argumento então é justamente o equilíbrio entre direitos individuais e defesa social, bem como a justificativa de redução de garantias do delinquente e/em defesa dos direitos da vítima, a partir, inclusive, de um discurso que concebe em ambos as diferenças no âmbito de sua humanidade, em termos muito semelhantes de Ferri.

Para Sodré, a Escola Clássica dava seus últimos suspiros e, embora ainda permanecesse nos Códigos e nos espíritos conservadores e misoneístas, inimigos da evolução, já estava superada na doutrina, pois entre os criminalistas sábios a Escola Antropológica tendia a tornar-se unânime e 
conquistaria “[...] definitivamente a palma da vitória nesta luta contínua de todos os dias em prol da verdade" (SODRÉ, 1977, p. 342).

Em sua opinião, próximo estava o momento em que a pena se mesclaria a todos os mecanismos de defesa social, uma vez que, pelos avanços da Ciência, o campo da irresponsabilidade, leia-se, anormalidade, apenas ampliava:

[...] à medida que o espírito humano se desenvolve e a ciência progride, mais amplo se torna o círculo da irresponsabilidade. Atualmente a classe dos irresponsáveis não é somente constituída pelos loucos de todos os gêneros; a ela também pertencem os surdos-mudos, os sonâmbulos, os ébrios, os hipnotizados. Natural é, pois, que se creia que não está longe o tempo em que será verdadeira banalidade o dogma da filosofia determinista de que todos os homens são moralmente irresponsáveis [...] A pena será então por todos encarada como uma medida de preservação social, tal como ora a compreende a escola antropológica, e não mais, por este lado, se distinguirá de nenhum outro sentimento de defesa social. (SODRÉ, 1977, p. 246)

Em Sodré isso não era visto de forma alarmante, como um perigo, muito pelo contrário, era uma consequência natural dos avanços da Ciência. Muito diferente, portanto, de Tobias Barreto, para quem, ainda no final do século XIX, lucidamente previa que levadas às últimas consequências as premissas da Antropologia Criminal, todos seriam internados em um manicômio (BARRETO, 2003, p. 70).

\section{Filinto Bastos: um clássico fiel}

Filinto Bastos é baiano, abolicionista, começou a Faculdade de Direito em São Paulo, fazendo o último ano na Faculdade de Recife, concluído em 1882, ano em que voltou para a Bahia, onde assumiu o cargo de promotor público na comarca de Camisão; em 1884 assume o cargo de juiz municipal da mesma comarca. Com a República, foi nomeado juiz de carreira tendo exercido este cargo em Caetité, Caravelas e Amargosa. Em 
1892, foi promovido para a capital como juiz de primeira entrância, tornando-se, depois de cinco anos, desembargador do Tribunal de Revista e Apelação da Bahia. Nesse mesmo ano, tornou-se professor da Faculdade da Bahia, exercendo a cátedra até a sua morte em 1939. Foi um dos fundadores da Academia de Letras da Bahia e sócio do Instituto Geográfico e Histórico do mesmo estado.

Tomou-se como base para analisar a recepção das ideias do Positivismo Penal neste autor a publicação das Breves Lições de Direito Penal do jurista, publicadas também no ano de 1906.

O jurista inicia suas aulas delimitando o campo jurídico e definindo sua autonomia em relação a outras Ciências - para esse autor a Ciência do Direito Penal não deve se confundir com a Antropologia Criminal e a Sociologia Criminal (subdivisões, como define Liszt da Criminologia) e deve, portanto, abordar o delito e a pena como fatos da ordem jurídica. $\mathrm{O}$ delinquente, o delito e a pena devem estar sob as vistas desta Ciência, que não deixa de socorrer-se dos ensinamentos das outras que mais de perto se ocupam do homem e dos fenômenos da vida física e moral (a Filosofia, a História do Direito, a Ciência Política e a Política Criminal, a Economia, a Estatística Criminal, a Antropologia, a Medicina Judiciária, a Polícia Médica) (BASTOS, 1906).

Quando se analisa os diferentes sistemas que explicam o direito de punir, ponto comum entre vários programas da disciplina de Direito Criminal, dispara contra as Teorias Contratualistas, as Teorias Moralistas e as Teorias Utilitárias ${ }^{4}$, filiando-se à Teoria Eclética, na qual combinam-se a noção de justiça absoluta e a utilidade/necessidade da conservação social (Carrara). Sua filiação à Escola Clássica é bastante clara. Assim afirma:

Sem embargo do variado matiz das opiniões e dos conceitos que vieram modificar ou enriquecer o plano primitivo da Escola Clássica, esta se tem mantido nos códigos criminaes, nas lições e nos

${ }^{4}$ Critica o sistema de Bentham, maculado de um puro utilitarismo, que suprimindo o elemento moral das ações humanas, ignorando a noção de justiça, impõe “"[...] como razão ultima do direito de punir o interesse publico, este systema chega ás mais deploráveis consequências, exigindo o predomínio da força á altura de principio da sciencia do governo". (BASTOS, 1906, p. 16). 
tratados dos sábios, resistindo ás teorias que pretendem annullal-a, mostrando, portanto, a elevação dos princípios cardeais da sua doutrina e a utilidade pratica que de sua aplicação colhe constantemente a humanidade. (BASTOS, 1906, p. 26)

Rebate as afirmações de Ferri de que a Escola Clássica teria chegado ao seu fim histórico, estando os seus sectários condenados a uma discussão bizantina de fórmulas escolásticas e um exercício infecundo de ruminação científica. Considera tais críticas exclusivistas e autoritárias, além de baseadas em trechos colhidos de obras clássicas e analisadas fora de seu contexto para forçar uma interpretação mais conveniente (BASTOS, 1906).

Não aceita a crítica positiva de que a Escola Clássica teria prescindido do delinquente, pontuando várias hipóteses em que os Códigos levam em conta questões subjetivas e pessoais do criminoso para definir sua imputabilidade e pena:

[...] as questões referentes á edade, aos estados pathologicos, ao erro, á coação, ao medo irresistível, á reincidência, ás circuntancias agravantes e atenuantes, á surdimudez, á legitima defesa e á imminencia de um mal maior; a aplicação de certas penas ás mulheres e aos velhos; a atenção á maternidade em certos delictos; o parentesco, e muitas outras relações; deixam patente que se a Escola Clássica estudava o delicto como uma abstração jurídica, o estudava também como uma realidade produzida pelo criminoso. (BASTOS, 1906, p. 28)

Sobre o delito natural de Garofalo, coaduna-se com as objeções de Tarde (ter se apoiado como ponto fixo para analisar o crime exatamente em algo tão fluido quanto a sensibilidade), considerando vago este conceito e, portanto, não sendo critério seguro de uma fórmula geral. Assim, em sua visão, "A noção de Garofalo, se não erige o crime em entidade abstracta, como tanto se censurou aos clássicos, não é tão precisa e determinada que imponha a abolição da noção do crime segundo os juristas" (BASTOS, 1906, p. 75). 
Sobre o criminoso típico, dispara uma crítica irônica a Ferri e aponta que até mesmo Lombroso teria dele desistido:

Ferri procurou lançar o ridículo sobre 'este caixilho symetrico das consequências jurídicas e abstractas onde os juízes tinham de colocar, á fina força, a pessoa viva e real de cada criminoso' mas não se lembrou talvez de que ao caixilho tão artisticamente emoldurado pelos brilhantes sectários da ecsola anthropologica havia de faltar sempre a personagem sonhada que nelle devia figurar - o criminoso typico, ou melhor, o typo anthropologico do criminoso - criatura já repudiada pelo creador, que se convenceu da chimera que tomou como realidade, principio illusorio de uma escola, desfeito pela confissão do mesmo Lombroso, seu genial inventor. (BASTOS, 1906, p. 106)

Filinto Bastos, ainda, não admite a responsabilidade social. Para ele, a punição não se justifica apenas nos interesses sociais. A sociedade não é causa das faculdades humanas, mas apenas meio para estas se realizarem. Resiste à concepção organicista da sociedade que tende a ver no indivíduo uma simples célula,

[...] confundido-o com os demais seres, até supprimir-lhe a responsabilidade moral, para fazer recair sobre ele a pena, como o cão hydrophobo o toxico mortífero, essa tendência não chegará a convencer os que levam as teorias ao ultimo exagero que está dita a ultima palavra: haverá para estes uma eterna incógnita; e deles se poderá dizer o que da doutrina de Ferri disse Dallemagne: 'Ha uma indeterminação a pesar sobre esta teoria como um ponto de interrogação. A doutrina de Ferri termina por um X. (BASTOS, 1906, p. 110)

Mas também não entende o direito de punir como passível de concessão por parte dos particulares. Assim posiciona-se quando analisa o consentimento do ofendido como não excludente ou dirimente da intenção criminosa. Para Filinto Bastos (1906), os sujeitos não podem consentir na violação de seus direitos individuais - a ordem social existe para garanti-los e não está subordinada aos caprichos dos indivíduos. 
É curioso verificar que nesse ponto manifesta-se diversamente Ferri. Segundo o jurista italiano, todos os direitos são em alguma medida inalienáveis e intangíveis e, em outra, alienáveis e tangíveis. O único critério positivo de limitação é o da necessidade de existência social. Para Ferri (1979, p. 60), “[...] o direito é inviolável apenas até onde não chega a necessidade de existência social" ${ }^{5}$. E esse princípio vale inclusive para o direito à vida, à existência humana. Na visão do autor, assim como o homem tem o direito de viver, tem o direito de morrer, sendo o direito à vida um direito passível de renúncia.

Ainda que considere não existir uma separação absoluta entre moral e direito, Ferri admite que, embora o suicídio possa ser considerado um ato reprovável em termos morais e religiosos, no âmbito social e jurídico, considera um direito do homem dispor de sua vida.

Os argumentos em contrário devem pressupor a questão: a sociedade e a família têm direito sobre a existência de qualquer um de seus membros? Ferri aponta que se poderia supor nesta linha de argumentos a corrente socialista, em que o Estado tem uma preeminência sobre o indivíduo e estabelece quase um domínio sobre a vida individual. Mas ressalta ser justamente das correntes ligadas ao individualismo a sua defesa.

Característica importante da Escola Positiva, para Ferri, e que inclusive corresponde a uma oposição à Escola Clássica, na sua opinião, é a valorização do equilíbrio entre direitos individuais e sociais. A crítica de Ferri é que a Escola Clássica prioriza excessivamente os primeiros em detrimento da sociedade. Pois bem: ao mesmo tempo em que se pode dizer que o centro da Escola Clássica seja o indivíduo e o cerne da Escola Positiva seja a sociedade, quando se diz respeito ao suicídio, a perspectiva mais "liberal" associa-se a Ferri - é justamente um dos mestres da Escola Positiva que defende maior autonomia ao indivíduo. E o autor mesmo indica que são as correntes individualistas que sustentam que a sociedade tem direito sobre a existência de seus membros. Estar-se-ia diante de uma contradição? Não necessariamente. Se pensarmos que os suicidas eram

\footnotetext{
${ }^{5}$ Tradução livre de: "il diritto è intangibile soltanto fin dove non arriva la necessità della esistenza sociale."
} 
vistos pelos positivistas como degenerados, assim como os criminosos, legitimar o suicídio por meio de um argumento que concilia direitos individuais e interesse social parece uma boa saída para justificar a eliminação dos mais fracos - uma seleção que interessa, portanto, à própria sociedade. Trata-se da adaptação do discurso: em relação aos suicidas, cuja eliminação interessa, prevalece o direito individual de morrer; "deixar morrer"; em relação ao criminoso, prevalecem os interesses da defesa social e, portanto, aqui pode-se inclusive "fazer morrer" (penas eliminatórias, defendidas pelos integrantes da Escola Positiva).

Tanto é assim, que em seu texto L'omicidio-suicidio, Ferri deixa claro que na sociedade também deve prevalecer o princípio da seleção natural, em que os mais fracos são eliminados, sendo o suicídio e a eutanásia mecanismos funcionais para isso. De acordo com Accattatis, o princípio da seleção natural absorvido pelos teóricos da Escola Positiva adveio da leitura de Haeckel, em que este princípio adquire uma dose diferente da de Darwin (ACCATTATIS, 1979).

Nessa obra, Ferri defende que o homem não tem obrigação de existir, de viver. Se o homem tem o direito de emigrar (deixar sua sociedade) também deve ter o direito de suicidar-se. Ferri, inclusive, demonstra a influência do pensamento de Malthus, segundo o qual uma das causas da miséria social é o excesso populacional (ACCATTATIS, 1979).

No meio social, assim como na biologia, os mais fracos tendem a perecer, e o suicídio corresponde ao ato daqueles mais fracos na luta pela existência, também um tipo de seleção (no meio social) para que ocorra o melhoramento humano nas gerações futuras. Assim, na sociedade, alguns têm o direito de viver, outros o direito de morrer, em benefício mesmo do organismo social (que tende a eliminar suas células doentes e mais fracas) (ACCATTATIS, 1979).

Como não admite a responsabilidade social, Bastos defende a Teoria da Responsabilidade Moral, que liga a punição ao livre-arbítrio. Filinto Bastos esclarece que para a Escola Clássica que segue esta lógica, não se trata de uma vontade que direciona a ação sem motivos. Trata-se, porém, de uma vontade que diante dos motivos pode discernir entre eles 
- por mais forte que possam ser os motivos que direcionam a uma determinada ação, a vontade, à luz da consciência, pode guiar-se de maneira contrária - é ato do homem a apreciação dos motivos que atuam na vontade, bem como a determinação tomada em virtude desta apreciação - é um ato do homem e não dos motivos. Assim: "O motivo que concorre para a determinação não pode executar-se senão mediante a vontade; e esta, por assim dizer, fecundando-o, dá vida á determinação, que é incontestavelmente um fenômeno da atividade livre" (BASTOS, 1906, p. 112).

De acordo com Filinto Bastos, a visão de responsabilidade moral, sem livre-arbítrio, propugnada pela Escola Crítica, segundo a qual a vontade é o "eu" desposando o motivo, acaba recaindo no livre-arbítrio. Questiona: "Mas, porque se casa com o motivo o eu? É impelido por uma força que lhe elimina a liberdade, ou por acto de sua voluntariedade livre?" (BASTOS, 1906, p. 116-117). Faz objeção ao jurista brasileiro José Hygino, filiado a esta Escola, que elaborou o prefácio da tradução do Tratado de Direito Criminal, de Von Liszt, no sentido de que este teria confundido livre-arbítrio com fatalismo, ao vincular exclusivamente ao determinismo a ideia de que a vontade é determinável por motivos. Assim responde:

Ora, o livre-arbítrio não se resolve, como bem diz Pessina - em uma volição puramente casual e sem motivo - uma vontade indeterminada. Uma escola, como a clássica, que inspirou os códigos das nações cultas e tanto melhorou o estado social; uma escola que considera o motivo reprovado, o motivo frívolo - o ajuste - a traição - circunstamcias agravantes - o não pleno conhecimento do mal - as ameaças, o constrangimento physico vencível - atenuantes; não pode considerar o homem um joguete da fatalidade nem sobre o fatalismo se podia assentar o edifício inabalável da civilização [...] O que devemos entender pela capacidade que o homem tem de resolver-se autonomamente por motivos [...]? [...] vem a ser: o poder de resolver-se por si mesmo, mediante motivos, - isto é: o homem pode resolver-se livremente, tendo em vista os motivos do seu acto. Ora isto é, por uma fraseologia mais espiosa, o reconhecimento da liberdade moral, do livre-arbítrio do homem. (BASTOS, 1906, p. 118) 
E conclui ironizando os deterministas: "Mas se assim é, porque tanta celeuma contra o livre-arbítrio - a pedra de escândalo - dos deterministas?" (BASTOS, 1906, p. 120). De fato, se analisarmos a maneira pela qual os positivistas concebem o livre-arbítrio, pode-se perceber que eles criam uma leitura equivocada do livre-arbítrio, como uma vontade completamente desprendida da realidade e, ao se apegarem ao "rasteirismo" dos fatos, vinculam os homens a uma causalidade tal que elimina toda possibilidade de autodeterminação.

Quando discorre sobre a relação sexo e responsabilidade, também rebate as teses, dos antropologistas, de que a mulher, por características especiais, como sensibilidade exaltada e impressionável, predominância do instinto à razão e as especificidades orgânicas de determinados períodos (gravidez, parto, menopausa), deveriam ter uma responsabilidade diminuída. Em sua opinião,

[...] não se hão de suprimir á mulher as luzes da razão, nem the eliminar ao coração as influencias da moralidade, simplesmente porque não pertence ao sexo masculino. Considerar-se a mulher inferior ao homem na compreensão dos deveres sociaes não é uma these que tenha por si o consenso da civilização, mormente hoje que o feminismo se ergue altivo, reivindicando até os direitos políticos, e disputando todas as profissões. (BASTOS, 1906, p. 177)

Menciona mesmo Puglia, o qual considerava, embora provadas as diferenças orgânicas e psíquicas das mulheres, não haver necessidade de estabelecer menor responsabilidade, apenas adaptando a aplicação do sistema penitenciário e aplicando atenuantes caso fosse comprovado que determinado estado orgânico interferiu na determinação criminosa (BASTOS, 1906, p. 177).

Um dos únicos aspectos que segue a Escola Positiva é a defesa da instituição dos manicômios criminais. Em sua opinião deveria caber aos peritos analisar o grau de perigo da loucura e ao juiz, ponderando a avaliação pericial, determinar a entrega para familiares ou encaminhar para um hospital específico para loucos que tivessem cometido crimes (BASTOS, 1906). 
Quanto à reincidência, critica o Código Republicano por ter previsto a reincidência específica, que define de maneira bastante restrita o crime de mesma natureza como violação do mesmo artigo. E nesse momento utiliza-se do termo "temível" para referir-se, agora, ao reincidente. Assim se expressa: "O individuo que, depois de uma condenação, comete um novo crime, seja ou não da mesma natureza daquele por que foi condenado, revela-se mais temível ou mais perigoso que os outros delinquentes." (BASTOS, 1906, p. 250). Dessa forma, demonstra uma visão rigorosa em relação ao reincidente. Mas, ainda assim, é contrário ao estado permanente de reincidência (como propõe Garofalo, por exemplo). Entende de utilidade social a consideração da passagem do tempo entre a condenação e a prática de novo delito, mas em sua opinião esta deve ser combinada com a análise da conduta do indivíduo durante este período - averiguada conduta imoral e reprovada do delinquente durante este lapso temporal, não há porque se contar com a brandura da lei. O jurista entende que com a reincidência não se está punindo mais uma vez o mesmo delito, mas punindo mais rigorosamente o criminoso que revela maior temibilidade (BASTOS, 1906).

Em sua opinião a pena é sim um mal justo em resposta a um mal injusto praticado pelo delinquente; tem função de restabelecer a ordem perturbada, purificar a atmosfera moral da comunhão (contendo os inclinados ao mal e animando os bons) e corrigir o criminoso. Elenca os devidos princípios constitucionais que devem orientar a penalidade: a pessoalidade da pena; que esta ainda não seja infamante, aplicando-se apenas na medida de castigá-lo (devem ser, portanto, aflitivas), sem rebaixar sua dignidade, e de corrigi-lo para que regenerado volte à sociedade. Assim, "[...] a pena ameaça, a pena castiga. Ameaçando, ensina, adverte e intimida; castigando, instrue, intimida e pode produzir a emenda do criminoso" (BASTOS, 1906, p. 283). Discorda dos postulados da Escola Antropológica, para a qual a pena não tem quase efeito algum no controle da criminalidade e dá destaque aos substitutivos penais. Fazendo uso das palavras de Zanardelli, defende que

Ainda que circumscripta á eficácia puramente relativa que caracteriza o efeito de todas as funções sociaes e politicas, a lei penal 
é chamada a prestar um precioso serviço de defesa, a que poderão contrastar ordinários e extraordinários sucessos, calamidades sociaes e perfídias de malvados, mas que não deixará jamais de exceder a sua influencia na educação civil de um povo em proveito da segurança publica e privada. (BASTOS, 1906, p. 284)

$\mathrm{O}$ autor, ainda, é contrário à pena de morte e julgou acertada sua eliminação do Código, depois confirmada pela Constituição, o que teria, em sua opinião, seguido os "hábitos do povo brasileiro" e à aspiração nacional. Para ele, enquanto a sociedade puder fazer uso do sistema penitenciário, deve evitar meios repressivos eliminadores, opinião que mais uma vez destoava e contrapunha-se à da grande maioria da Escola Positiva, defensores de meios eliminadores, sobretudo para os criminosos anormais incorrigíveis.

Menciona a indeterminação da pena e a condenação condicional, mas não deixa claro seu posicionamento a respeito, apenas apresentando opiniões a favor e outras contrárias. Filinto Bastos participou do Primeiro Congresso Juridico Brazileiro em que se decidiu que as sentenças indeterminadas, desde que a indeterminação seja relativa, não são vistas como prejudicais às garantias da liberdade individual.

Nesse jurista baiano, abolicionista e aparentemente simpático ao movimento feminista, pode-se perceber então uma resistência consistente aos postulados centrais da Escola Positiva, calcada em um Liberalismo que pende para a liberdade do indivíduo, mais que para a segurança da sociedade e de viés mais democrático, uma vez que nele não está presente a premissa da dualidade da humanidade. Assim, em termos gerais, defende a autonomia do Direito em face da Antropologia e Sociologia Criminais; defende que os interesses sociais não devem se sobrepor aos direitos individuais, pois o indivíduo não é apenas uma célula no corpo social; afirma a utilidade da pena; sustenta a liberdade da vontade e a responsabilidade moral como critério da punição; repele o tipo criminoso e, ainda, para ele, como nos termos da Escola Clássica, o criminoso não corresponde a um tipo anômalo. Assim explicita: "é certo que a Escola Clássica admitindo a igualdade fundamental de todos os homens, delinquentes ou não, repele o princípio da Escola Antropológica de ser 
o delinquente - um tipo anômalo, uma variedade distinta do genus homo (Garofalo)". (BASTOS, 1906, p. 28)

Dessa forma, percebe-se que neste autor não prevalece a premissa da cisão entre os homens feito pela norma, e a ausência deste pressuposto talvez seja uma das razões, além da delimitação do âmbito jurídico em face da invasão das demais Ciências, em fazê-lo resistir aos postulados da Escola Positiva, "nadando contra a corrente", uma vez que, na primeira década do século XX, a disseminação e adesão à Nova Escola no âmbito do ensino do direito criminal tendem a se intensificar.

\section{Conclusão}

Tanto na Itália quanto no Brasil, a Criminologia emerge e se desenvolve em um contexto político, econômico e social de intensas transformações - o Estado se reconfigurando; a Economia assumindo os contornos do Capitalismo; a sociedade adotando o modelo burguês individualista; e o Direito, inclusive e com grande destaque, o Direito Penal, tentando acompanhar esse processo e delimitá-lo em suas doutrinas e leis. Esse processo é próprio e peculiar em cada país, mas em ambos produz rachaduras e ao mesmo tempo conforma continuidades e, junto a ele, emergem questões sociais problemáticas que demandam da Ciência respostas e soluções ou mesmo justificativas para determinadas respostas e soluções que assumem um caráter repressivo e excludente, num contexto em que o discurso político e jurídico liberal afirmam a igualdade e liberdades. Nessa conjuntura, a questão do controle social e, necessariamente, a questão penal assumem uma centralidade e o discurso criminológico é uma das linguagens adotadas pelo Direito Penal para conduzir determinadas práticas que se chocavam, aparentemente, com o discurso liberal, pois, por exemplo, o argumento da defesa social que deve prevalecer aos direitos individuais, a cisão da humanidade entre normais e anormais, e a ideia de perigo e temibilidade, elementos centrais do Positivismo Penal, relativizavam os limites das garantias e legitimavam medidas de caráter autoritário. 
Aparentemente porque pode-se dizer que o Liberalismo, em que pese se expressar como um ideário de afirmação de direitos e garantias individuais, ao longo do século XIX, ele também foi marcado por cortes de exclusão e, portanto, combinou-se, na prática, com mecanismos de poder e controle, em nome da segurança e defesa da sociedade. Assim, o discurso liberal sempre se caracterizou pela dualidade inclusão/exclusão, ordem/liberdade; Direito/poder: de um lado, a liberdade e os direitos dos indivíduos (proprietários); de outro, a segurança e defesa da sociedade e poder do Estado ${ }^{6}$. Essa dualidade liberal se reproduz no Direito Penal e se ramifica em duas correntes - uma liberal e de caráter mais garantista (chamada Escola Clássica pelos positivistas) e outra de base Crimonológica (positiva).

No âmbito da cultura jurídica brasileira esta dualidade, no campo da Ciência Criminal, foi assumida por dois juristas célebres do período analisado: Moniz Sodré, o qual declarava-se liberal e aderia convictamente à Nova Escola, enquanto Filinto Bastos apoiava-se na dogmática bem elaborada pela Escola Clássica e mantinha-se fiel aos seus postulados liberais penais: igualdade jurídica e liberdade.

Compreender a absorção do discurso criminológico, marcado por este embate de Escolas, Clássica e Positiva, no Brasil da Primeira República pode ajudar a identificar e mesmo legitimar/justificar estas dualidades. Aqui a defesa da sociedade e a cisão da Humanidade se embasam em um discurso também liberal, como se viu em Sodrè. Isso porque, ao mesmo tempo em que o direito das garantias individuais se aplica a alguns, o

\footnotetext{
${ }^{6}$ Domenico Losurdo propõe uma releitura do Liberalismo que acabe com o mito de que seu percurso foi apenas marcado pela conquista de direitos (dos civis aos políticos). A comunidade dos livres buscava afirmar estes direitos pela exclusão de tantos outros. A exclusão permeou a tradição liberal desde o seu início. Isto fica claro não apenas levando em conta a exclusão das populações coloniais, justificada pelo argumento racial, pois vistas como selvagens e de raça inferior, mas a exclusão do espaço sacro da liberdade de camadas da população no interior dos países que se proclamavam impérios da liberdade, como a Inglaterra e os Estados Unidos. O Liberalismo conviveu com a escravidão dos negros, a dizimação dos índígenas e a semi-escravidão das classes pobres brancas cujo destino, muitas vezes, eram a morte ou a internação em instituições. O que Losurdo busca mostrar é que o Liberalismo não se afirma a despeito destes fatos, mas todos eles estão entrelaçados com o projeto liberal (LOSURDO, 2005).
} 
direito da norma, do perigo, da suspeição e da prevenção deve se aplicar a outros. A dualidade do Estado e do poder liberal corresponde à dualidade de sujeitos e reflete uma dualidade de discursos no Direito Penal (Direito Penal do ato - Direito Penal do autor) que, todavia, se analisarmos mais a fundo, pertencem à mesma herança cultural (o Iluminismo reformador), ligada à construção de um novo modelo social (burguês-moderno) que produz também seu próprio sujeito ideal (racional, autônomo, produtivo) e sua antítese (vagabundo, ocioso, criminoso, anormal).

Se lei (princípio da legalidade, garantias individuais)/norma (normalização, práticas de polícia) constitui uma dualidade que caracteriza o Estado Liberal, em que a exclusão é, de certa forma, constitutiva, quando o Brasil assimila este modelo de Estado e poder parece adequar também esta lógica dual, a qual lhe parece bastante pertinente, pois ocorre em uma sociedade em que a dualidade de sujeitos era prévia, evidente e constitutiva e a exclusão/marginalização naturalizada e enraizada na mentalidade social brasileira.

\section{Referências}

ACCATTATIS, V. Introduzione. In: FERRI, E. Sociologia Criminale. Milão: Feltrinelli, 1979. p. 9-51.

BARRETO, Tobias. Menores e Loucos em Direito Criminal. Brasília: Senado Federal; Conselho Editorial, 2003.

BASTOS, F. Breves Lições de Direito Penal: de conformidade com o programa adoptado na Faculdade Livre de Direito da Bahia. Bahia: Libro-Typographia Almeida, 1906.

COSTA, P. Pagina introdutiva (Il principio di legalità: un campo di tensione nella Modernità Penale). Quaderni Fiorentini, [S.l.], v. XXXVI, 2007.

DIAS, Rebeca Fernandes. Criminologia no Brasil: Cultura Jurídica Criminal na Primeira República. Rio de Janeiro: Lumen Juris, 2017. FERRI, E. Sociologia Criminale. Milão: Feltrinelli, 1979. 
LOSURDO, D. Controstoria del liberalismo. Roma-Bari: Editora Laterza, 2005.

QUEIROZ, R. M. R. A Modernização do Direito Penal Brasileiro. São Paulo: Quartier Latin, 2007.

SBRICCOLI, M. Caratteri originari e tratti permanenti del sistema penale italiano (1860-1990). In: VIOLANTE, L. Storia d'Italia. Annali 14. Legge Diritto Giustizia. Turim: Giulio Einaudi editore, 1998. p. 487-567. SBRICCOLI, M. La penalistica civile: Teoria e Ideologie del diritto Penale nell'Italia Unita. In: SBRICCOLI, M. Storia del diritto penale e della giustizia. Tomo I Scritti editi e inediti (1972-2007). Milão: Giuffrè Editore, 2009. p. 493-590.

SODRÉ, M. As três escolas penais: clássica, antropológica e crítica (estudo comparativo). 8. ed. Rio de Janeiro: Freitas Bastos, 1977.

Rebeca Fernandes Dias é doutora em Direito pela Universidade Federal do Paraná (UFPR) e pela Università degli Studi di Firenze (2015). Professora de História do Direito na Faculdade UniDomBosco de Curitiba. Professora de Teoria do Estado e do Poder e História e Socioantropologia do Direito na Pontifícia Universidade Católica do Paraná (PUCPR). Graduada em Direito pela Universidade Federal do Paraná (2004). Mestre em Direito pela Universidade Federal do Paraná (2007). Coordena o grupo de pesquisa, na UniDomBosco de Curitiba, "Direito, poder e subjetividade e Direito e Modernidade Líquida". Integrante do núcleo de pesquisa "Direito e Subjetividade e História do Direito", coordenado pelo Professor Doutor Ricardo Marcelo Fonseca, na Universidade Federal do Paraná (UFPR).

E-mail: rebecadias7@gmail.com

Endereço profissional: Rua Imaculada Conceição, Prado Velho, Curitiba, PR. Avenida Presidente Wenceslau Braz, n. 1.172, Guaíra, Curitiba, PR. CEP: 81010-000. ORCID: https://orcid.org/0000-0003-2725-7562 